\title{
FROM 'POLITICAL ECONOMY' TO 'POLITICAL SOCIOLOGY' OF THE CLIMATE CATASTROPHE: WHY THE ECONOMY NEEDS TO BE BLOWN UP TO BE BORN AGAIN?
}

\author{
MARIUSZ BARANOWSKI ${ }^{1}$ \\ ${ }^{1}$ Adam Mickiewicz University in Poznań, Szamarzewskiego 89 C, 60-568 Poznań, Poland. ORCID: \\ 0000-0001-6755-9368, Email: mariusz.baranowski@amu.edu.pl
}

\begin{abstract}
The conceptual approach to real social phenomena and problems, as well as factors influencing and shaping them, although theoretical in nature, has momentous practical consequences. The issue of nature, and in a narrower sense of climate, constitutes a telling and representative example of the implications of the theoretical and methodological orientation adopted to study society and its relationship with the environment and its resources. This short paper aims to highlight the consequences of the shift in research perspective from 'political economy' to 'political sociology' in the context of climate change and its challenges. The article's main argument is to outline the implications of the change of reference point for the conceptualisation and operationalisation of theoretical frameworks related to social problems and challenges, which, nota bene, are conditioned directly and indirectly by the state of the ecosystem. And the central thesis is that a fundamental reorientation towards nature and climate change within the dominant capitalist system will only be a camouflaged maintenance of the status quo (accompanied noisily by a series of technological and fiscal solutions that solve nothing).
\end{abstract}

KEYWORDS: political sociology, political economy, climate change, natural environment, social welfare, degrowth 


\section{INTRODUCTION}

Dolitical economy, a term first introduced in 1615 [2017] by mercantilist proponent Antoine de Montchrestien (Montchrétien) in his work Traité de l'œeconomie politique, refers to "the study of how a country-the public's household-is managed or governed, taking into account both political and economic factors" (Veseth \& Balaam 2020: n.p.). Neoclassical economists seem not to have fully assimilated the information that, however, "[e]conomics is a social science. It is neither a branch of mathematics nor the study of nature. It is, instead, analysis of humans by humans" (Wolf 2018: xiii). However, relations between people are both mediated by and influence nature. It would be difficult to imagine studying the processes of production, distribution, and exchange of means of satisfying individual and social needs without taking nature into account. In addition, economists, including contemporary ones, have failed or refused to recognise the increasing and irreversible costs of environmental exploitation and their secondary effects on the socio-economic system (with its attendant inequalities and injustices).

If we try to look at the current situation from a distance, we can see the absurd stubbornness of continuing with the dominant model of economic development, which completely ignores the question of the general social welfare, nature and "techno-scientifically produces risks" (Beck 1992: 19).

\section{THE POVERTY OF ECONOMICS?}

Although political economy-irrespective of the different ways it is understood by, for example, Adam Smith or Marxists-contains strongly articulated historical and social components, its primary domain of interest is economic. This fact is not altered by emphasising its sociopolitical connections, as in the following excerpt:

Political economy, branch of social science that studies the relationships between individuals and society and between markets and the state, using a diverse set of tools and methods drawn largely from economics, political science, and sociology. The term political economy is derived from the Greek polis, meaning 'city' or 'state,' and oikonomos, meaning 'one who manages a household or estate.' (Veseth \& Balaam 2020: n.p.)

In the context of the 'problem' of nature and climate change, and the search for alternative modes of production, visions of the economy other than capitalist ones must be developed, because "[i]t is possible, therefore, that economic theory may continue to function mainly as a surrogate ideology for the market economy, right up until the day, in some distant future, when society evolves into something so profoundly different it no longer warrants the moniker 'capitalism'” (Keen 2011: 5).

To achieve this, one needs, above all, a sociological imagination (cf. Mills 2000 [1959]) rather than an economic one (Baranowski 2011; Kassner 2021; Ziółkowski 2021). However, the latter will be crucial for building a system for meeting social needs, or social welfare, under new social conditions (Baranowski 2019). All the more reason to watch the evolution of particular heterodox economics, breaking with the approach 
that “a market economy necessarily maximizes social welfare” (Keen 2011: 65). This is particularly important because the purely instrumental and commodity-like treatment of nature and the environment has gained ground under the neoliberal type of capitalism. This variety of dominant economic system fetishises economic growth, systematically privatises, commodifies and deregulates various areas of life, generating environmental devastation and marginalising the weakest social groups (cf. Abercrombie 2020; Ziółkowski, Baranowski, \& Drozdowski 2020).

It can no longer be ignored in the design of economic solutions from the fact that "since 1970 (...) the number of birds, mammals, reptiles and amphibians has dropped by more than half. A quarter of all species are at risk of extinction” (IPBES 2019 as cited in Hickel 2020: 26). These hard facts (based on 15,000 studies), combined with the consequences of rising global temperatures, set key planetary boundaries (Rockström et al. 2009) that many schools of economics ignore but whose severe consequences will affect everyone.

Even what are described as progressive approaches to economics, by which I mean MMT (Modern Monetary Theory), while challenging the fiscal and monetary assumptions of mainstream economics, do not offer comprehensive solutions to the climate challenge or to reducing the commodification of nature. I am not saying that the issue of money creation and the inflation mechanism is not important at all. But they are secondary to the real challenges we face. Let us look at the statement of L. Randall Wray in Modern Money Theory, which shows a bold re-evaluation of 'professed' and taught formulas, and let us ask ourselves the role of MMT in reducing the negative impact of economies on the environment:

Imagine how the policy discourse will be changed when our President could no longer claim that 'Uncle Sam has run out of money'; when our government can no longer refuse to create jobs, or to build better infrastructure, or to put astronauts on Mars because of lack of funds; or when pundits would no longer be allowed to raise the scary spector of striking 'bond vigilantes' who might refuse to 'lend' more to government! There may be reasons we want to leave millions of workers unemployed, or to live with unsafe bridges and highways, or to remain earth-bound, but lack of funding cannot be one of them. (Wray 2015: 8)

In perspective adopted in this article, what MMT offers is no alternative either to externalising the costs of economic growth to the environment or to undermining popularised consumption styles. And without these solutions and their underlying phenomena, such as commodification, basing the economic model on economic growth, and the predatory exploitation of nature, we will not stop the coming ecological disaster (Walker, Druckman, \& Jackson 2021).

\section{DOES ‘POLITICAL’ SOCIOLOGY MAKE A DIFFERENCE?}

Politically and civically oriented sociology (more in the Burawoy's [2005] sense of public sociology) offers much more in a radical change of lifestyles, that is, behaviours, motivations, needs, and values. And it must be remembered that implementing 
post-capitalist scenarios in the form of, e.g. degrowth, is not a simple task (Romano 2020; Smith, Baranowski, \& Schmid 2021). It involves a complete re-evaluation of the world as we know it, from its tiniest details at the personal level (cf. Heimburg \& Ness 2021), through mid-range institutional solutions (cf. O’Brien \& Penna 1998), to issues of geopolitical relations (cf. Cichocki \& Jabkowski 2019; Lekkai 2020; Lemańczyk \& Baranowski 2021) that have never been ultimately settled.

We must not forget that sociology has historically played-and can still play-a servile role to the dominant political, economic and cultural powers. A critical view of sociology and its application should be an immanent and distinctive feature of the discipline.

One of the 'positive' sticking points in this highly complicated and challenging situation is that we simply must work out (and very quickly) concrete solutions for reducing consumption and completely changing the economic model. The other option is out of the question. The second point concerns the wisdom of the people themselves, who anticipate progressive solutions without waiting for the decisions of politicians and business people. As Christian Felber, an Austrian economist and the creator of the concept of the Economy for the Common Good (ECG), noted, "[w]herever you meet people in any country in the world, who know themselves well, they reject intuitively capitalism" (The Mint 2017).

Even Adam Smith, who is considered the father of economics (Norman 2018), very eloquently and unambiguously characterised 'the great proprietors' with the following words: "All for ourselves, and nothing for other people, seems, in every age of the world, to have been the vile maxim of the masters of mankind" (Smith 2003: 525). In another passage the Scottish thinker used the term "the principal architects" (Smith 2003: 841).

Beyond these 'principal architects', however, there is an essential part of the population whose position, even within liberal and most developed economies, leaves much to be desired. The data presented in Figure 1 on relative poverty, i.e. the share of people living with less than half the median disposable income in their country, show that both the USA, UK, Australia and Canada are above the OECD average. These are countries categorised as shareholder capitalism and the residual welfare state model. But for the record, we also find Israel, Japan and Korea above the OECD average.

Even being aware of the weakness of this indicator, that "it precludes the possible existence of 'absolute' or 'primary' poverty as this is conventionally understood" (Marx \& den Bosch 2008), it-and a number of other measures-cannot be ignored in stigmatising systemic socio-economic inequalities. These inequalities not only exclude a huge part of the population from full citizenship, that is, from responsibility for the fate of the community (Parenti 2010), but also deprive them of real control over the 'the masters of mankind' in environmental matters (Klitkou et al. 2017; Kopnina et al. 2021). Over four decades ago, Howard Zinn (1980: 565-566) wrote in A Peoples's History of the United States taht "where there was a powerful drive for profit overriding concern for human welfare, as in a capitalist system, the dangers were multiplied, and the remedies more difficult to achieve". 


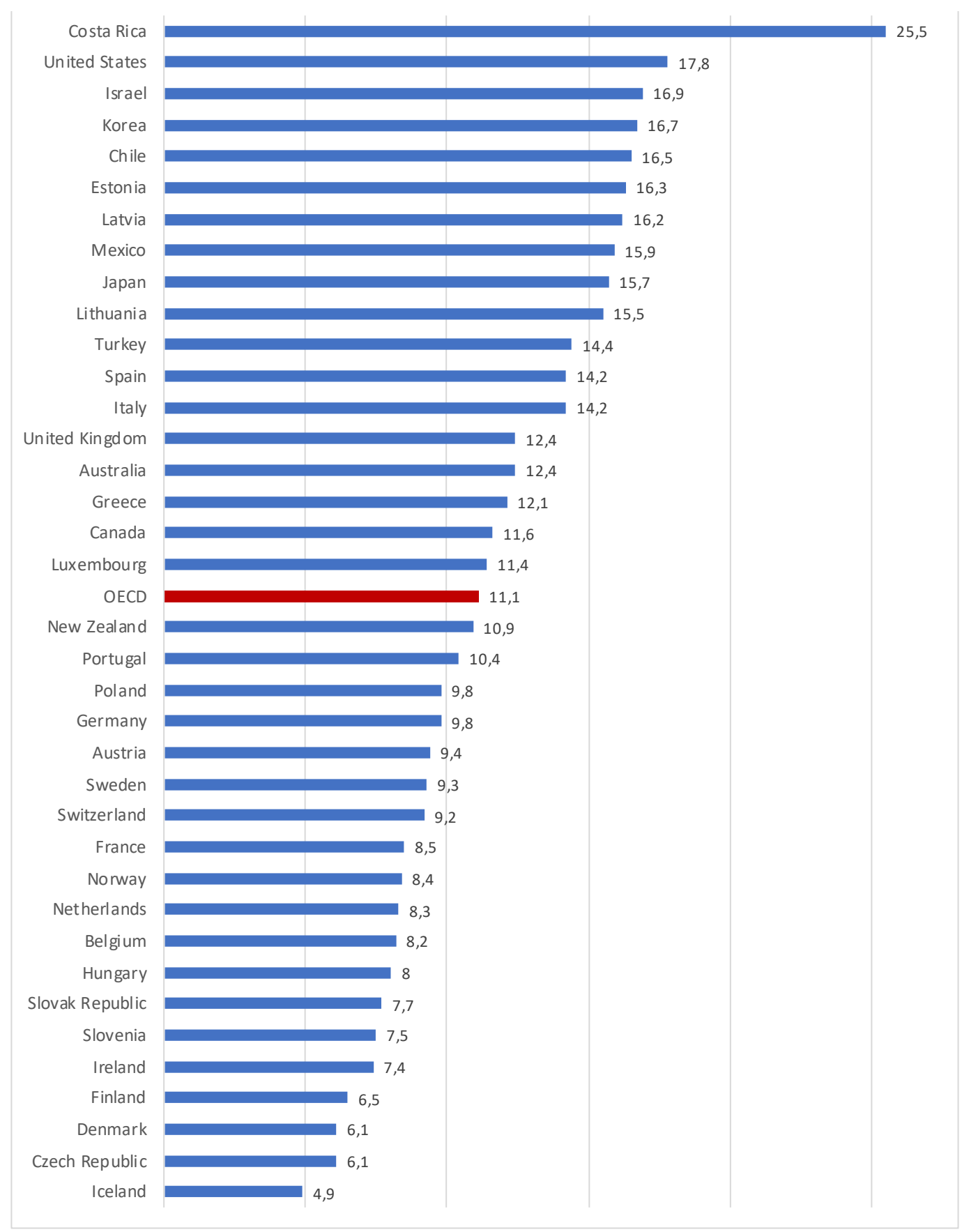

Figure 1. People living in relative poverty

$\%$ of population with less than half the middle income in their country, 2019 or nearest year Source: OECD Income Distribution Database

\section{CONCLUSION}

However, let us remember 'a sociological theory of a political economy' as described by Charles Wright Mills in the following interdisciplinary way:

As each social science advances, its interaction with the others has been intensified. The subject matter of economics is again becoming what it was in the 
beginning - the 'political economy,' which is increasingly viewed within a total social structure. An economist such as John Galbraith is as much a political scientist as Robert Dahl or David Truman; in fact his work on the current structure of American capitalism is as much a sociological theory of a political economy as Schumpeter's view of capitalism and democracy or Earl Latham's of group politics. Harold D. Lasswell or David Riesman or Gabriel Almond is as much a sociologist as a psychologist and a political scientist. (Mills 2000: 139)

In order to radically reformulate the foundations of the existing economic 'order' in the context of the climate crisis, 'a sociological theory of a political economy' must be replaced by a progressive vision of political sociology aimed at (i) redefining capitalist social relations and (ii) working out the foundations of a 'post-capitalist society', since "democracy itself is either marking time or in retreat; it is everywhere under threat" (Amin 2003: 1). This line of thinking also resounds in Tim Jackson's book Prosperity without Growth, particularly in the passage emphasising the social foundations ofwhat the British researcher calls-'prosperity', and what I prefer to refer to as 'social welfare':

For at the end of the day prosperity goes beyond material pleasures. It transcends material concerns. It resides in the quality of our lives and in the health and happiness of our families. It is present in the strength of our relationships and our trust in the community. It is evidenced by our satisfaction at work and our sense of shared meaning and purpose. It hangs on our potential to participate fully in the life of society. (Jackson 2009: 16)

This significant observation shifts the focus from economics to the broader field of social relations. It also takes into account the ecological barriers of our planet, so commonly ignored and disregarded. And yet-as Tim Jackson (2009: 16) continues-“" $[\mathrm{p}]$ rosperity consists in our ability to flourish as human beings-within the ecological limits of a finite planet. The challenge for our society is to create the conditions under which this is possible. It is the most urgent task of our times”.

If our task is a real transformation of the economic model towards respect for nature and a halt to climate change, the primary objective is a political sociology of change, not only in lifestyles, but above all in the ways in which decisions are made and social welfare is realised, which must necessarily be nature-based social welfare.

FUNDING: This research received no external funding.

CONFLICT OF INTEREST: The author declares no conflict of interest.

\section{REFERENCES}

Abercrombie, Nicholas. 2020. Commodification and Its Discontents. Cambridge, UK: Polity Press. 
Amin, Samir. 2003. Obsolescent Capitalism: Contemporary Politics and Global Disorder. New York: Zed Books.

Amin, Samir. 2011. Maldevelopment: Anatomy of a Global Failure. Cape Town: Pambazuka Press.

Baranowski, Mariusz. 2011. “The Property Rights Theory Approach from a Socio-Economic Viewpoint.” Studia Historiae Oeconomicae 28-29: 3-16. https://pressto. amu.edu.pl/index.php/sho/article/view/29215

Baranowski, Mariusz. 2019. "The struggle for social welfare: Towards an emerging welfare sociology." Society Register 3(2): 7-19. https://doi.org/10.14746/ sr.2019.3.2.01

Beck, Ulrich. 1992. Risk Society: Towards a New Modernity. Transl. M. Ritter. London: SAGE Publications.

Burawoy, Michael. 2005. "For Public Sociology.” American Sociological Review 70(1): 4-28. https://doi.org/10.1177/000312240507000102

Cichocki, Piotr \& Piotr Jabkowski. 2019. “Immigration attitudes in the wake of the 2015 migration crisis in the Visegrád Group countries: Comparative insights of ESS7 and ESS8.” Intersections 5(1): 27-47. https://doi.org/10.17356/ieejsp.v5i1.480

Danecki, Jan, Jerzy Krycki, \& Danuta Markowska, eds. 1993. Insights Into Maldevelopment: Reconsidering the Idea of Progress. Warsaw: University of Warsaw, Institute of Social Policy.

de Montchrestien, Antoine. 2017. Traité de l'œconomie politique. Paris: Classiques Garnier.

Hickel, Jason. 2020. Less is more: How degrowth will Save he World. London: Random House.

IPBES. 2019. Global Assessment Report on Biodiversity and Ecosystem Services, edited by E. S. Brondizio et al. Bonn: IPBES secretariat. https://doi.org/10.5281/zenodo. 3831673

Jackson, Tim. 2009. Prosperity without Growth: Economics for a Finite Planet. London and Sterling, VA: Earthscan.

Kassner, Maciej. 2021. „Jak opisać dynamikę polityczną polskiej transformacji?” Przegląd Krytyczny 3(1): 19-50. https://doi.org/10.14746/pk.2021.3.1.2

Keen, Steve. 2011. Debunking Economics - Revised and Expanded Edition. The Naked Emperor Dethroned? London and New York: Zed Books.

Klitkou, Antje et al. 2017. Bioeconomy and digitalization. Stockholm: MISTRA (The Swedish Foundation for Strategic Environmental Research).

Kopnina, Helen, et al. 2021. "Ecodemocracy in practice: exploration of debates on limits and possibilities of addressing environmental challenges within democratic systems." Visions for sustainability 15: 9-23. https://doi.org/10.13135/2384$\underline{8677 / 5832}$

Lekkai, Ina. 2020. “Unaccompanied refugee minors and resilience: A phenomenological study.” Przegląd Krytyczny 2(1): 33-54. https://doi.org/10.14746/pk.2020.2.1.03

Lemańczyk, Magdalena \& Mariusz Baranowski. 2021. Die deutsche Minderheit als (Mehr-)Wert: Analysen aus der Woiwodschaft Oppeln. Göttingen: V\&R unipress.

Marx, Ive \& Karel van den Bosch. 2008. "How poverty differs from inequality on pov- 
erty measurement in an enlarged EU context: Conventional and alternative approaches.” Retrieved September 18, 2021 (https://ec.europa.eu/eurostat/documents/1001617/4577263/1-1-I-MARX.pdf).

Mills, Charles Wright. 2000. The Sociological Imagination. With a new Afterword by Todd Gitlin. Oxford and New York: Oxford University Press.

Norman, Jesse. 2018. Adam Smith: Father of Economics. New York: Basic Books.

The Mint. 2017. “Interview with Christian Felber: The Common Touch.” September 15, 2017. Retrieved September 18, 2021 (https://www.themintmagazine.com/interview-with-christian-felber-the-common-touch).

O’Brien, Martin \& Sue Penna. 1998. Theorising Welfare: Enlightenment and Modern Society. London: SAGE.

OECD Income Distribution Database. 2021. Retrieved September 18, 2021 (https://www. oecd.org/social/inequality-and-poverty.htm?fbclid=IwAR3aJPTIkFq0_k4yMLF6uhkqGq7OunJxG8se6zg0vMlo13HomEsjaFm2Eds \&utm_content=\&utm_medium=social\&utm_source=facebook\&utm_term=PAC).

Parenti, Michael. 2010. Democracy for the Few. $9^{\text {th }}$ edition. Boston: Wadsworth.

Rockström, Johan et al. 2009. "Planetary Boundaries: Exploring the Safe Operating Space for Humanity.” Ecology and Society 14(2): 32. http://www.ecologyandsociety.org/vol14/iss2/art32/

Romano, Onofrio. 2020. Towards a Society of Degrowth. London and New York: Routledge.

Smith, Adam. 2003. The Wealth of Nations. Introduction by Alan B. Krueger. New York: A Bantam Book.

Smith, Thomas S. J., Mariusz Baranowski, \& Benedikt Schmid. 2021. “Intentional degrowth and its unintended consequences: Uneven journeys towards post-growth transformations." Ecological Economics 190: 107215. https://doi.org/10.1016/j. ecolecon.2021.107215

Veseth, Michael A. \& David N. Balaam. 2020. "Political economy." in Encyclopedia Britannica, 22 May. 2020. Retrieved September 5, 2021 (https://www.britannica. com/topic/political-economy).

Von Heimburg, Dina \& Ottar Ness. 2021. "Relational welfare: A Socially just response to co-creating health and wellbeing for all." Scandinavian Journal of Public Health 49: 639-652. https://doi.org/10.1177/1403494820970815

Walker, Christine C., Angela Druckman, \& Tim Jackson. 2021. "Welfare systems without economic growth: A review of the challenges and next steps for the field.” Ecological Economics 186: 107066. https://doi.org/10.1016/j.ecolecon.2021.107066

Wolf, Martin. 2018. "Foreword." Pp. xiii-xiv in Rethinking Economics: An Introduction to Pluralist Economics, edited by L. Fischer, J. Hasell, J. Ch. Proctor, D. Uwakwe, Z. Ward-Perkins, \& C. Watson. London and New York: Routledge.

Wray, L. Randall. 2015. Modern Money Theory: A Primer on Macroeconomics for Sovereign Monetary Systems. $2^{\text {nd }}$ edition. Basingstoke: Palgrave Macmillan.

Zinn, Howard. 1980. A Peoples's History of the United States. London and New York: Longman.

Ziółkowski, Marek. 2021. „Postmonocentryczny ład społeczny i jego dynamiczny 
charakter: Dwie przeciwstawne konstelacje kulturowe.” Przegląd Krytyczny 3(1): 7-19. https://doi.org/10.14746/pk.2021.3.1.1

Ziółkowski, Marek, Mariusz Baranowski, \& Rafał Drozdowski. 2020. “On the Multiple Varieties, Consequences and Paradoxes of the Commodification of Nature." Polish Sociological Review 211(3): 281-300. https://doi.org/10.26412/psr211.02

\section{BIOGRAPHICAL NOTE}

Mariusz Baranowski is assistant professor of sociology at the Adam Mickiewicz University, Poznań, Poland.

OPEN ACCESS: This article is distributed under the terms of the Creative Commons Attribution Non-commercial License (CC BY-NC 4.0) which permits any non-commercial use, and reproduction in any medium, provided the original author(s) and source are credited.

ARTICLE HISTORY: Received 2021-07-25 / Accepted 2021-10-15 
